\title{
Puffy feet in a female neonate
}

\author{
Rita Espírito Santo, ${ }^{1}$ Oana Moldovan, ${ }^{2}$ Paula Costa, ${ }^{1}$ André Graça, \\ Margarida Abrantes ${ }^{1}$
}

1 Department of Pediatrics, Service of Neonatology, Hospital Santa Maria-CHLN Academic Medical Center of Lisbon, Lisboa, Portugal ${ }^{2}$ Department of Pediatrics, Service of Genetics, Hospital Santa Maria-CHLN, Academic Medical Center of Lisbon, Lisboa, Portugal

\section{Correspondence to} Dr Rita Espírito Santo, a.r. espiritosanto@gmail.com

Accepted 26 July 2016

\section{DESCRIPTION}

A female neonate was evaluated due to limb oedema. Her father and three older siblings were healthy. Her mother had a subclinical autoimmune hypothyroidism. Gestation was uneventful, except for an abnormal maternal serum screening for aneuploidy during the first trimester. Amniocentesis revealed a normal female karyotype. A normal vaginal delivery occurred at 39 weeks. Physical examination showed bilateral dorsum foot oedema (figures 1 and 2). Cerebral ultrasound was normal and echocardiography revealed a patent foramen ovale. She was discharged at 48 hours of life and had regular follow-up consultations in neonatology, physical medicine and rehabilitation, paediatric cardiology and genetics. Later, the family learned about some paternal relatives with swollen legs and feet.

Congenital primary lymphoedema can be caused by several genetic diseases (Trisomy 13, 18 and 21,

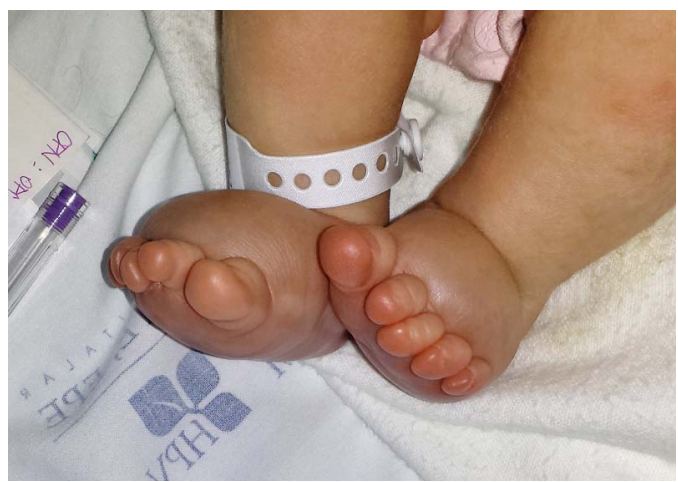

Figure 1 Bilateral lymphoedema of the lower limbs at first physical examination of the neonate.

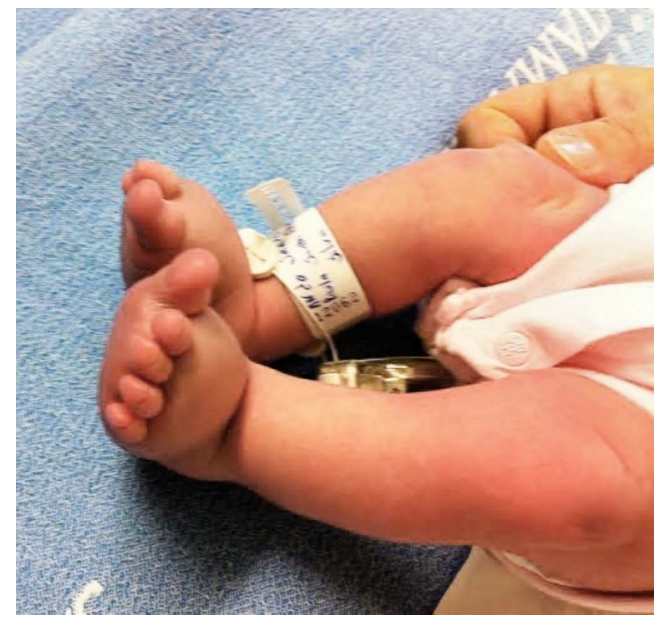

Figure 2 Bilateral lymphoedema of the lower limbs at first physical examination of the neonate.

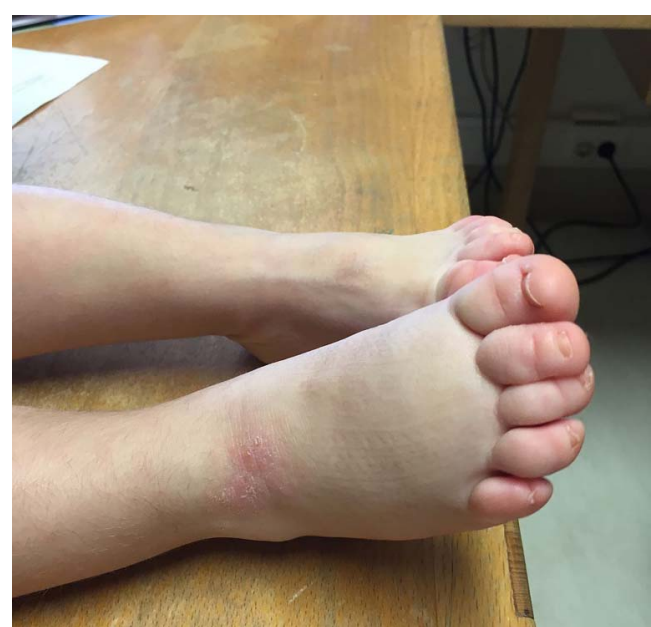

Figure 3 The appearance of the feet at 18 months.

Turner syndrome, Noonan syndrome, lymphoedema-distichiasis or yellow nail syndrome). As she had an isolated lymphoedema, normal karyotype and a positive family history, a Milroy's disease was considered. This diagnosis was confirmed by the identification of a mutation in FTL4/VEGFR3 gene.

Milroy's disease is a developmental disorder of the lymphatic system which leads to disabling and disfiguring swelling of the extremities. It is a rare condition with an estimated frequency of 1:6000. ${ }^{12}$ This disease shows an autosomal dominant pattern of inheritance with penetrance of 80 $90 \%{ }^{2}$ It is considered a benign disorder which, nonetheless, can be associated with cellulitis, upslanting toenails and papillomatosis. ${ }^{3}$

Currently, our patient is 18 months old and has a normal growth and development. She presents mild-to-moderate asymmetric bilateral lymphoedema of the lower limbs (figure 3).

\section{Learning points}

When evaluating a neonate with oedema of the lower limbs genetic causes should always be considered. If the infant has no other associated malformations, Milroy's disease is also a possibility. ${ }^{13}$

- Milroy's disease is an autosomal dominant form of primary lymphoedema characterised by a congenital onset and non-progressive lower limb involvement. ${ }^{1}$
Treatment for Milroy's disease is conservative based on physical therapy, simple elastic compression with garments and exercise. ${ }^{12}$ 
Acknowledgements Mariana Soeiro e Sá.

Competing interests None declared.

Patient consent Obtained.

Provenance and peer review Not commissioned; externally peer reviewed.
2 Brice $\mathrm{G}$, Child AH, Evans $\mathrm{A}$, et al. Milroy disease and the VEGFR-3 mutation phenotype. J Med Genet 2005;42:98-102.

3 Yilmaz AE, Sarifakioglu E, Gorpelioglu C, et al. Puffy feet in an 11-month-old infant: a quiz. Milroy disease. Acta Derm Venereol 2009;89:668-70.

\section{REFERENCES}

1 Kitsiou-Tzeli S, Vrettou C, Leze $E$, et al. Milroy's primary congenital lymphedema in a Male infant and review of the literature. In Vivo 2010;24:309-14.

Copyright 2016 BMJ Publishing Group. All rights reserved. For permission to reuse any of this content visit http://group.bmj.com/group/rights-licensing/permissions.

BMJ Case Report Fellows may re-use this article for personal use and teaching without any further permission.

Become a Fellow of BMJ Case Reports today and you can:

- Submit as many cases as you like

- Enjoy fast sympathetic peer review and rapid publication of accepted articles

- Access all the published articles

- Re-use any of the published material for personal use and teaching without further permission

For information on Institutional Fellowships contact consortiasales@bmjgroup.com

Visit casereports.bmj.com for more articles like this and to become a Fellow 